\title{
New Pharmacological Opportunities for Betulinic Acid
}

Authors

José Luis Ríos, Salvador Máñez

Affiliation

Departament de Farmacologia, Facultat de Farmàcia, Universitat de València, Burjassot, Spain

Key words

betulinic acid, metabolic syndrome, antiviral, antitumor, parasiticidal, anti-infectious

received September 15, 2017

revised November 7, 2017

accepted November 13, 2017

Bibliography

DOI https://doi.org/10.1055/s-0043-123472

Published online December 4, 2017 | Planta Med 2018; 84: 8-

19 (c) Georg Thieme Verlag KG Stuttgart · New York I

ISSN 0032-0943

Correspondence

Prof. José Luis Ríos

Departament de Farmacologia, Facultat de Farmàcia,

Universitat de València

Av. Vicent Andrés Estellés s/n, 46100 Burjassot, Spain

Phone: + 34963544973 , Fax: + 34963544943

riosj|@uv.es

\section{ABSTRACT}

Betulinic acid is a naturally occurring pentacyclic lupane-type triterpenoid usually isolated from birch trees, but present in many other botanical sources. It is found in different plant organs, both as a free aglycon and as glycosyl derivatives. A wide range of pharmacological activities has been described for this triterpenoid, including antiviral and antitumor effects. In addition, several other interesting properties have been identified in the fields of immunity and metabolism, namely antidiabetic, antihyperlipidemic, and anti-inflammatory activities. Taken together, these latter three properties make betulinic acid a highly interesting prospect for treating metabolic syndrome. The present review focuses on the therapeutic potential of this agent, along with several of its semisynthetic derivatives, which could open new frontiers in the use of natural product-based medicines.

\section{Introduction}

Betulinic acid, or 3 $\beta$-hydroxy-lup-20(29)-en-28-oic acid ( $\bullet$ Fig. 1), is a naturally occurring pentacyclic lupane-type triterpenoid widely distributed in plants [1]. Usually isolated from known medicinal plants, such as the birch tree (Betula sp., Betulaceae), it has also been found in various species of the genera Ziziphus (Rhamnaceae), Syzygium (Myrtaceae), Diospyros (Ebenaceae), and Paeonia (Paeoniaceae). The compound is present in the plant as a free aglycon or as glycosylated derivatives [1] that are easily isolated from the source with different solvents, most commonly dichloromethane. Purification of the compound can be easily performed through a combination of different chromatographic methods [2]. Betulinic acid exhibits an array of pharmacological activities, some of which have been widely studied, such as its antiviral properties (especially against HIV) [3], as well as its cytotoxic and antitumor effects [4-8]. However, other interesting properties have been described for this compound, including antidiabetic [9], antihyperlipidemic [10], and anti-inflammatory [11] effects. This review focuses on these latter three properties, although other pharmacological effects, such as antimicrobial and antiparasitic activities, have also been described [1]. In the case of diabetes, hypercholesterolemia, and inflammation, our review groups these into the well-described entity known as metabolic syndrome.

For this review, we searched the Cochrane Library, Pubmed, Scopus, and the Web of Sciences for articles published from 2005 to the present. However, a selected number of relevant papers published before 2005 were also included for added insights included in the Introduction and Summary, Future Perspectives, and Conclusions sections. The key words used were betulinic acid, either alone or combined with metabolic syndrome, cholesterol, lipid, hyperlipidemia, hypercholesterolemia, hypertriglyceridemia, diabetes, insulin, liver, hepatoprotective, heart, blood pressure, hypertension, antiviral, antitumor, parasiticidal, and anti-infectious. Only articles written in English and published in peer-reviewed scientific journals were included. Both in vitro and in vivo studies were analyzed, along with clinical trials and other types of experiments in humans. About 300 papers were retrieved and analyzed, with only 94 being included in the final review. Articles were excluded if they included data from previous studies or if there was a repetition of data or similar results. 


$\begin{array}{ll}\text { ABBREVIATIONS } \\ \text { Akt } & \text { protein kinase B } \\ \text { AMPK } & \text { AMP-activated protein kinase } \\ \text { CAIX } & \text { carbonic anhydrase IX } \\ \text { CAMKK } & \text { Ca }^{2+} \text {-calmodulin dependent protein kinase kinase } \\ \text { CYP } & \text { cytochrome P450 } \\ \text { ER } & \text { estrogen receptor } \\ \text { GLUT } & \text { glucose transporter } \\ \text { GSK } & \text { glycogen synthase kinase } \\ \text { hACAT } & \text { human cholesterol acyltransferase } \\ \text { HIV } & \text { human immunodeficiency virus } \\ \text { IKB } & \text { inhibitor of nuclear factor } \kappa \text { B } \\ \text { IL } & \text { interleukin } \\ \text { mTOR } & \text { mammalian target of rapamycin } \\ \text { NF- } K B & \text { nuclear factor- } \kappa \text { B } \\ \text { PARP } & \text { poly-ADP-ribose polymerase } \\ \text { PGSK3 } \beta & \text { phosphor-glycogen synthase kinase } 3 \beta \\ \text { PI3K-B } & \text { phosphatidylinositol 3-kinase-dependent B } \\ \text { PLA } 2 & \text { phospholipase A } 2 \\ \text { PPAR } & \text { peroxisome proliferator-activated receptor } \\ \text { PTP1B } & \text { protein tyrosine phosphatase 1B } \\ \text { SOD2 } & \text { Mn-superoxide dismutase } \\ \text { SREBP1 } & \text { sterol regulatory element-binding protein 1 } \\ \text { TGR5 } & \text { bile acid membrane receptor } \\ \text { TNF- } \alpha & \text { tumor necrosis factor- } \alpha \\ & \end{array}$

\section{Metabolic Syndrome}

Metabolic syndrome is characterized by a series of interconnected physiological, biochemical, clinical, and metabolic factors, which directly increase the risk of cardiovascular disease and type 2 diabetes mellitus. Some of these risks, such as insulin resistance, atherogenic dyslipidemia, and endothelial dysfunction, can be prevented or treated [12]. The major risk factors for developing metabolic syndrome are physical inactivity and a diet high in fats and carbohydrates. Both contribute to central obesity and insulin resistance [13], which are associated with chronic inflammation, characterized by increased production of adipocytokines such as TNF- $\alpha$, IL-1, IL-6, leptin, and adiponectin [12]. For this reason, the reduction of central obesity and insulin resistance, along with the control of the proinflammatory state, are all desirable for avoiding atherogenic dyslipidemia and endothelial dysfunction in vascular inflammation. Natural products, such as betulinic acid, can modulate all these risk factors.

\section{Antidiabetic Properties}

Betulinic acid has been described as a potential antidiabetic agent of interest for the treatment of type 2 diabetes mellitus [9]. To this end, various in vitro and in vivo studies have been developed to establish the compound's activity and mechanism of action. Several studies have described its effects on absorption and uptake of glucose [14-16], insulin resistance and insulin sensitivity [17], and endogenous glucose production and synthesis of glycogen [18-
21]. In addition to these effects, a number of other relevant aspects of the compound's potential mechanisms have been established.

The first mechanism to be described was the inhibition of $\alpha$ amylase and $\alpha$-glucosidase, which diminishes the hydrolysis of polysaccharides. This leads to a clear reduction of free glucose and, consequently, a decrease in its absorption. The inhibitory effects on these enzymes and the delay in glucose absorption were demonstrated both in vitro and in vivo in mice. In addition, researchers were able to establish the active concentration and doses, which differed depending on the cell lines and animals used, varying from $14 \mu \mathrm{M}$ to $100 \mu \mathrm{M}$ [14-16].

The second mechanism is associated with increases in glycogen synthesis. In this way, betulinic acid stimulates glucose uptake and glycogen synthesis through the AMPK- GSK-3 $\beta$ pathway. In fact, betulinic acid $(10 \mu \mathrm{M})$ was shown to activate AMPK, thereby decreasing the expression of phosphoenolpyruvate carboxykinase and glucose-6-phosphatase [20]. Moreover, AMPK activation increases both glucose transport across the cell membrane and the expression of GLUT-1 and GLUT-2 [20,21].

Some relevant negative effects of type 2 diabetes mellitus are due to insulin resistance and $\beta$-cell dysfunction. These problems are thus a high priority in the treatment of the disease. In this context, Castro et al. [17] studied the effect of betulinic acid on intracellular signal transduction in glucose homeostasis and observed that rats treated with this triterpene $(10 \mathrm{mg} / \mathrm{kg}$, orally) produced a sustained insulin secretion and exhibited reduced levels of glycemia, with values close to those found in an euglycemic state.

Because different enzymes and pathways are implicated in insulin biosynthesis, secretion, and sensitivity, the PTP1B and PI3KB-Akt pathways constitute a good target for studying the effects and mechanisms of betulinic acid [17]. Indeed, in vitro, this triterpene $(0.70 \mu \mathrm{g} / \mathrm{mL})$ reduced human recombinant PTP1B activity by $95 \%$ [22], with an $\mathrm{IC}_{50}=3.5 \mu \mathrm{M}$ [23]. In vivo, treatment of hyperglycemic rats with betulinic acid $(10 \mathrm{mg} / \mathrm{kg}$, p. o.) increased the glycogen content and glucose uptake in muscles by acting as an insulin secretagogue and insulin mimetic agent via PI3K, mitogen-activated protein kinase, and mRNA translation [17]. It is well known that protein PTP1B inhibits PI3K/Akt signaling, which leads to the appearance of insulin resistance. In contrast, the inhibition of PTP1B increases the activity of the PI3K/Akt pathway, increasing glucose uptake into skeletal muscle both through the translocation of GLUT-4 to the plasma and membrane and by inhibiting gluconeogenesis [9].

The bile acid membrane receptor TGR5 is a G protein-coupled receptor that is normally expressed in brown adipose tissue and muscle. It acts as a cell surface receptor for bile acids, but is also implicated in energy homeostasis and insulin resistance [24]. Betulinic acid has TGR5 agonist activity with an $\mathrm{EC}_{50}=1.04 \mu \mathrm{M}$ and an efficacy of $83 \%$ [25]. The activation of the TGR5 receptor induces glucagon-like peptide- 1 secretion in different enteroendocrine cells and contributes to the effects of bile acids in glucose homeostasis, but other mechanisms may also be involved, such as the stimulation of oxidative phosphorylation [26,27]. The principal effects of betulinic acid on glucose metabolism are given in - Fig. 2. 


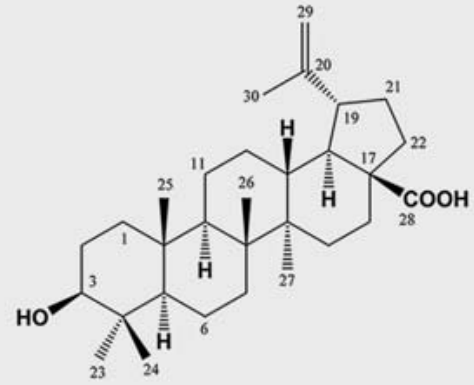

- Fig. 1 Chemical structure of betulinic acid.

\section{Effects on Dyslipidemia}

Betulinic acid $(50 \mathrm{mg} / \mathrm{L}$, administered in drinking water for 15 days) decreased total cholesterol and triglycerides in high-fat diet-induced obese mice [9]. The triterpene also decreased body weight, abdominal fat accumulation, blood glucose, plasma triglycerides, and total cholesterol. The results showed significant increases of insulin and leptin (anorexigenic hormone) in plasma, whereas the level of ghrelin (orexigenic hormone) decreased [15]. These effects explain the reduced appetite regulation observed in high-fat diet-induced obese mice [9]. Betulinic acid was shown to cause a greater decrease in plasma amylase activity than in that of lipase [15], but the results of studies conducted by Jang et al. [28] and Kim et al. [10] indicated that betulinic acid inhibits porcine pancreatic lipase $\left(\mathrm{IC}_{50}=21.1 \mu \mathrm{M}\right)$ and has a lipolytic effect mediated by cAMP-dependent phosphodiesterase inhibition, which could lead to the observed reduction of lipid absorption in the small intestine and the increase of fat mobilization [10]. Betulinic acid also reduces cholesterol absorption in the intestine via inhibition of hACAT. Indeed, the triterpene had an inhibitory effect on hACAT-1 (responsible for foam cell formation in macrophages) and hACAT-2 (responsible for the cholesterol absorption process in intestinal mucosal cells), with $\mathrm{IC}_{50}$ values of 16.2 and $28.8 \mu \mathrm{M}$, respectively [29].

In addition to its lipolytic effect in adipose tissues [10], betulinic acid reduced lipogenesis and lipid accumulation in various experimental models, both in vitro (HepG2 cells) and in vivo (ICR mice and Wistar rats) [30]. In the HepG2 cell assays, the following effects were demonstrated: suppression of intracellular lipid accumulation via modulation of lipogenic and lipolytic factors, inhibition of hepatic lipid accumulation via activation of the AMPK signaling pathway, increase of CAMKK expression, downregulation of the MTOR, and protein expression of S6 kinase. Ex vivo and in vivo assays showed the following effects: inhibition of SREBP1 activity and expression via modulation of a CAMKK-AMPK-mTOR-S6 kinase pathway in primary rat hepatocytes, suppression of hepatic triglyceride accumulation via modulation of a CAMKK-AMPKSREBP1 signaling pathway in the livers of ICR mice (high-fat diet), and suppression of triglyceridemia in ICR mice fed with a high-fat diet [30]. Activation of AMPK suppresses mRNA expression and nuclear translocation of SREBP-1 while positively regulating fatty acid oxidation through the activation of the PPAR- $\alpha$ and the PPAR $\gamma$

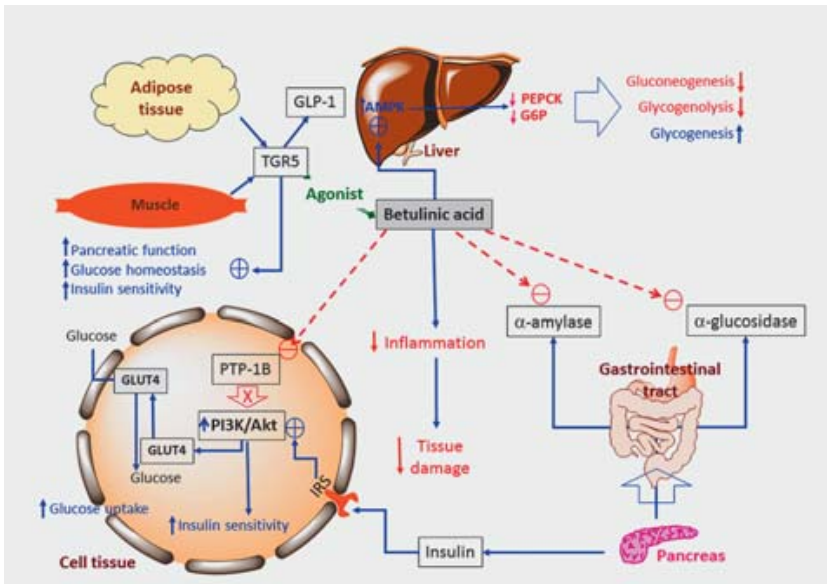

- Fig. 2 Effect of betulinic acid on glucose metabolism. Akt, protein kinase B; AMPK, AMP-activated protein kinase; G6P, glucose-6phosphate; GLP-1, glucagon-like peptide 1; GLUT-4, glucose transporter-4; IRS, insulin receptor substrate; PEPCK, phosphoenolpyruvate carboxykinase; PI3KB, phosphatidylinositol 3-kinase-dependent B; PTP1B, protein tyrosine phosphatase-1B; TGR5; bile acid membrane receptor.

coactivator (PGC)-1. These effects make sense because human PPAR $\alpha$ is expressed in several metabolically active tissues and plays a critical role in the regulation of cellular uptake, activation, and oxidation of fatty acids [31]. For its part, PGC-1 is expressed at high levels in both heart and skeletal muscle. Its expression decreases in situations associated with mitochondrial dysfunction, such as diabetes, suggesting that decreases in PGC-1 activity may contribute to this pathology [32]. In this context, betulinic acid may be able to regulate lipid homeostasis. Betulinic acid also inhibited diacylglycerol acyltransferase in rat liver microsomes $\left(\mathrm{IC}_{50}=9.6 \mu \mathrm{M}\right)$ in a noncompetitive manner, while also inhibiting triacylglycerol synthesis in HepG2 cells [33].

Taken together, these results indicate that betulinic acid may help reduce hepatic lipid accumulation by modulating the AMPK-SREBP signaling pathway, which would explain its hepatic antihyperlipidemic activity [30]. Several relevant aspects of the modification of lipid metabolism are summarized in > Fig. $\mathbf{3 .}$

\section{Anti-Inflammatory Effects}

Previous studies used various experimental models to demonstrate the anti-inflammatory activity of betulinic acid [11]. Indeed, this triterpene inhibited carrageenan-induced mouse paw edema by $46 \%$ (100 mg/kg), 12-O-tetradecanoylphorbol acetateinduced mouse ear edema by $86 \%$ ( $0.5 \mathrm{mg} / \mathrm{ear})$, and ethyl phenylpropiolate-induced mouse ear edema by $30 \%$ ( $0.5 \mathrm{mg} /$ ear). In addition, the vascular permeability caused by serotonin $(50 \mathrm{mg} / \mathrm{kg})$ in mice was blocked by the anti-glucocorticoid used in the experiment as well as by the mRNA or protein synthesis inhibitors, indicating that the compound may be a potential corticoid-like agent [2]. In complementary research, the same authors [34] studied the effects of betulinic acid on the inflammation induced by various activators of protein kinase $C$ and other agents. The results 


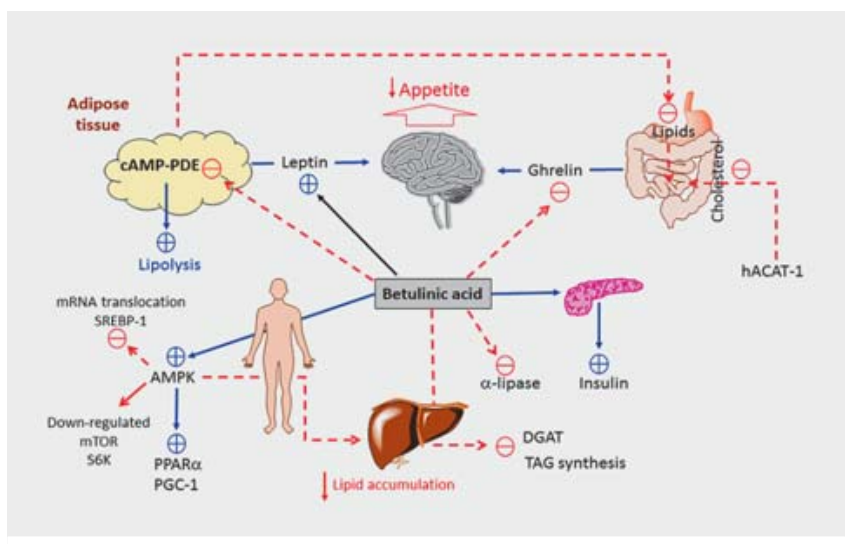

- Fig. 3 Regulation of betulinic acid on homeostasis, metabolism and oxidation of lipids. AMPK, AMP-activated protein kinase; CAMP-PDE, cyclic AMP-phosphodiesterase; DGAT, diacylglycerol acyltransferase; hACAT, human cholesterol acyltransferase; mTOR, mammalian target of rapamycin; PGC-1, PPARy coactivator-1; PPAR $\alpha$, peroxisome proliferator-activated receptor- $\alpha$; S6K, S6 kinase; SREBP1, sterol regulatory element-binding protein 1.

showed that betulinic acid $(0.5 \mathrm{mg} /$ ear) inhibited the edema induced by mezerein, 12-deoxyphorbol-13-tetradecanoate, and 12-deoxyphorbol-13-phenylacetate by 48,51 , and $61 \%\left(\mathrm{ID}_{50}=\right.$ $0.77 \mu \mathrm{mol} /$ ear in this case), respectively. Other positive effects were observed in bryostatin 1-induced mouse ear edema $(65 \%$ at $0.5 \mathrm{mg} /$ ear), bradykinin-induced mouse paw edema (54\% at $10 \mathrm{mg} / \mathrm{kg}$ ), and rat skin inflammation induced by glucose oxidase (39\% at $0.25 \mathrm{mg} / \mathrm{site})$. No effects were observed in ear edema induced by arachidonic acid, resiniferatoxin, or xylene. Because betulinic acid was inactive against arachidonic acid-induced inflammation as well as in neurogenic inflammatory models, it is likely that this type of inflammation may depend on in vivo inhibition of protein kinase $C$. This possible target was previously reported by Wang and Polya [35] in vitro against rat liver cyclic AMP-dependent protein kinase, wheat embryo $\mathrm{Ca}^{2+}$-dependent protein kinase, and rat brain protein kinase $C$, with $I C_{50}$ values of 45,84 , and $145 \mu \mathrm{M}$, respectively.

In other studies, betulinic acid also inhibited bovine pancreatic $\mathrm{PLA}_{2}$ by $40 \%(5 \mu \mathrm{M})$ [36], bovine prostaglandin synthase $\left(\mathrm{IC}_{50}=\right.$ $101 \mu \mathrm{M})$, and proinflammatory cytokine-induced neutrophil chemoattractant-1 $(34 \%, 1 \mu \mathrm{M})$ in stimulated rat macrophages and IL-1 $\beta$-stimulated rat fibroblast cells [37]. The triterpene $(30 \mu \mathrm{M})$ also suppressed NF- $\kappa \mathrm{B}$ activation induced by different agents as well as the NF- $\kappa B$-dependent gene expressions of cyclooxygenase- 2 and matrix metalloproteinase- 9 [38]. It selectively inhibited cyclooxygenase- $2\left(\mathrm{IC}_{50}=11.4 \mu \mathrm{M}\right)$ over cyclooxygenase- $1\left(\mathrm{IC}_{50}=\right.$ $115 \mu \mathrm{M})$ [39], and moderately reduced the production of nitric oxide in stimulated RAW 264.7 cells [40]. > Fig. 4 includes the principal in vivo effects of betulinic acid as well as its most relevant targets.

Bernard et al. [36] conducted a study relying on a combination of ethnopharmacological and bioinformatic information to discover new PLA 2 inhibitors. They verified not only that betulinic acid was docked into the PLA 2 crystal structure, but also that it could be inserted into the PLA 2 binding site with correct energy values.

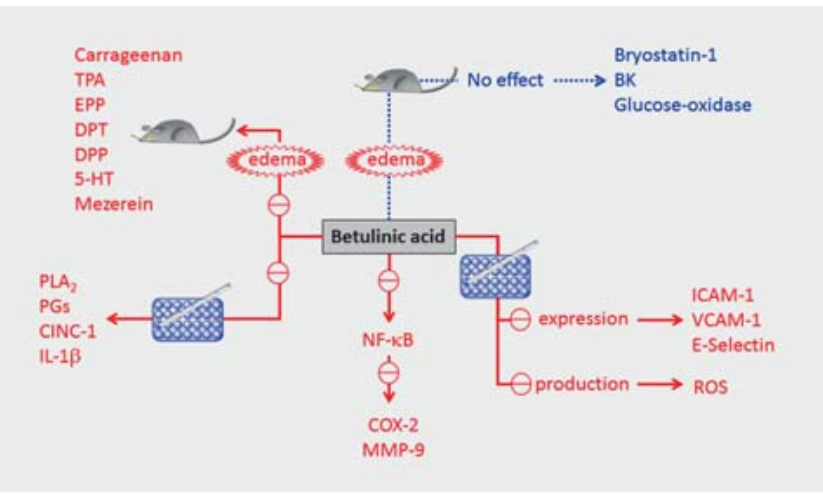

- Fig. 4 Anti-inflammatory effects and mechanism of betulinic acid against different agents. BK, bradykinin; CINC-1, cytokine-induced neutrophil chemoattractant-1; COX, cyclooxygenase; DPP, 12-deoxyphorbol-13-phenylacetate DPT, 12-deoxyphorbol-13-tetradecanoate; EPP, ethyl phenylpropiolate; E-selectin, endothelial cell selectin; 5-HT, 5-hydroxytriptamine (serotonin); ICAM-1, intracellular adhesion molecule-1; IL-1 $\beta$, inteleukin-1 $\beta$; MMP-9, matrix metalloproteinase-9; NF-kB, nuclear factor-KB; PG, prostaglandin; PKC, protein kinase $C$; $P L A_{2}$, phospholipase $A_{2}$; ROS, reactive oxygen species; TPA, 12-O-tetradecanoylphorbol acetate; VCAM-1, vascular cell adhesion molecule- 1 .

Moreover, of the compounds assayed, betulinic acid was the best inhibitor of $\mathrm{PLA}_{2}$. This result is in agreement with previous reports describing the importance of a carboxylate group for the inhibition of $\mathrm{PLA}_{2}$ [36] as well as with the results of previous triterpene studies [41-43].

Betulinic acid can also prevent vascular inflammation and atherosclerosis. Indeed, this triterpene (0.01-10.0 $\mu \mathrm{M})$ blocked the TNF$\alpha$-induced expression levels of intracellular adhesion molecule- 1 , vascular cell adhesion molecule-1, and endothelial cell selectin, all while reducing the production of reactive oxygen species and NF$\kappa B$ activation [44]. It also plays a protective role in the development of vascular inflammation and atherosclerosis via ATP-binding cassette transporter $A 1$, the expression of which is promoted through the downregulation of miR-33s, a family of microRNA precursors. This mechanism involves the suppression of $I_{K} B$ phosphorylation, p65 phosphorylation, and nuclear translocation as well as the transcription of the related NF- $\kappa \mathrm{B}$-dependent gene [45].

\section{Endocrinological and Cardiovascular Effects}

As mentioned above, PTP1B is an enzyme involved in several processes such as diabetes, inflammation, and cancer. Interactions with PTP1B are thus of great pharmacological interest. The vast majority of molecules that inhibit this enzyme do so by binding to the active cationic site; however, several lupane-derived triterpenes have been described as allosteric inhibitors because they interact with a hydrophobic zone of the protein. Betulinic acid, like betulin, lupeol, and lupenone, acts through hydrophobic interactions with the residues Ala189, Leu192, Phe196, Phe280, Trp291, and Leu294 of PTP1. In addition, it forms hydrogen bridges through its two polar, alcoholic, and acidic functions with the residues Glu276, Gln288, and Lys292. Lupeol and betulinic acid have 


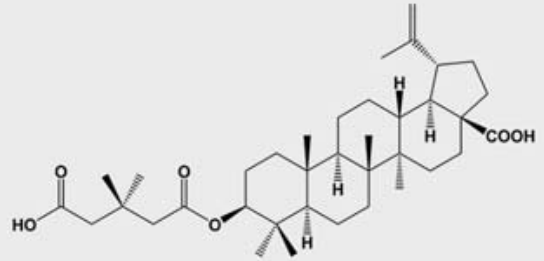

- Fig. 5 Chemical structure of bevirimat.

also been shown to inhibit TNF $\alpha$-induced PTP1B expression in mouse hypothalamic cells while also exhibiting the highest potency as inhibitors of enzyme activity, with $\mathrm{IC}_{50}$ values of 5.6 and $1.5 \mu \mathrm{M}$, respectively [46].

Betulinic acid's interaction with the ER has also been assessed; in fact, the acid was recently characterized as one of the antiestrogenic principles of Prunella vulgaris L. (Lamiaceae). In addition, it was shown to inhibit the genomic response to estradiol and to reduce the mRNA of growth regulation by estrogen in breast cancer 1 protein (GREB1) in MCF7 cells. Moreover, it reduced the expression of ER- $\alpha$ [47]. Another way that betulinic acid restricts estrogen signaling is through its effect on the Pygopus protein, the expression of which is strongly indicative of breast cancer, both at the cultured cell level and in samples of invasive ER- and ER+ tumors. Betulinic acid affects the coactivation of the estrogen-responsive gene promoter by transcription factor SP-1 (specificity protein-1), a step that entails a synergistic effect with antagonists or selective estrogen modulators [48].

These reports describe mechanisms involving genomic effects, since they correspond to classic pathways of so-called nuclear or hormonal signaling. However, betulinic acid has also been shown to exert a type of non-genomic activation of estrogen function, as described by Hohmann et al. [49]. Such an effect likely occurs upstream of the production of nitric oxide as a result of the increase in nitric oxide synthase activity in endothelial cells, an effect that was blocked by estrogen antagonist ICI182780. The authors postulated that the activation of the enzyme comes from rapid phosphorylation of the Ser1177 residue.

\section{Antiviral Activity}

Although several reports on the antiviral activity of betulinic acid have been published, the most recent reviews focus almost exclusively on its anti-HIV activity $[3,50]$. Our survey therefore covers only the latest studies and research.

Betulinic acid acts against HIV by preventing the cleavage of the capsid-spacer peptide of the Gag protein, thereby impeding viral maturation. This causes the host cell to release virions with no infective capacity. The efficacy of betulinic acid is influenced by various polymorphisms in this protein, especially in the residues 369-371 (QVT in wild type), with one of the best known being V370A. In a study carried out by Swidorski et al. [51], various derivatives were studied, namely C-28 amides carrying a C2-C3 double bond and a benzoic moiety at $\mathrm{C}-3$. The most potent inhibitors of viral expansion in MT-2 cells were the ethylene diamine deriva- tives, including pyridin-methylamines, at C-28 $\left(\mathrm{EC}_{50}=2-7 \mathrm{nM}\right)$. The benzoic substitution at $\mathrm{C}-3$ was also present in many of the 2,3-dehydrobetulin and 2,3-dehydrobetulinic acid derivatives assayed by Liu et al. [52], which all bore the bare natural $-\mathrm{CH}_{2} \mathrm{OH}$ or $-\mathrm{COOH}$ substitution, respectively. The most potent compounds $\left(\mathrm{EC}_{50}<50 \mathrm{nM}\right)$ were those with an ortho halogen substitution in the benzoic moiety of the dehydrobetulinic and betulin derivatives, and the simple benzoic or phthalic acids of dehydrobetulin.

One of the betulinic acid derivatives with the most widely recognized antiviral activity is bevirimat ( $\triangleright$ Fig. 5), the C-3 ester of 2,2-dimethylsuccinic acid, which was synthesized in 1996 by Kashiwada et al. [53] and which has been the subject of several previous studies. Bevirimat-related compounds lacking the carboxyl C-28, where an ethylamine chain is substituted by linear or cyclized alkylamines, have been described by Urano et al. [54]. Evaluated in terms of the level of reverse transcriptase activity, the antiviral potency of all the compounds assayed was higher against wild-type than against the V370A mutant, with the exception of the $\mathrm{N}$-hydroxyethylpiperidine derivative. However, the fluorination of bevirimat in different positions did not improve its potency in comparison with the parent group [55].

Studies of the antiviral activity of betulinic acid, along with research on various other triterpenes, have previously demonstrated an effect against herpes viruses, notably against the most common clinical strain, HSV-1. The different effects shown against this strain by the main triterpenes from the bark of birch trees (Betula sp.) were studied by Heidary Navid et al. [56], who evaluated the exact moment of application in in vitro treatment. After incubating the active principle with the virus, both sensitive and acyclovir-resistant strains lost their infectivity. However, neither pretreatment of the cell nor administrations at the time of viral propagation were effective.

Among the different possibilities for increasing the efficacy of betulinic acid as an antiviral agent, the most interesting is perhaps that envisaged by Visalli et al. [57], who sought to form polar derivatives on the $-\mathrm{COOH}$ in 28 , either directly by neutralizing the acid with choline, or indirectly through the formation of intermediary glycinamides followed by the formation of salts of choline or benzalkonium. This type of structural modification results in increased solubility, and hence a better absorption and greater effect, as demonstrated by improvements in the potency of several compounds $\left(\mathrm{IC}_{50}=0.6-0.9 \mu \mathrm{M}\right)$ in relation to betulinic acid $\left(\mathrm{IC}_{50}=\right.$ $1.6 \mathrm{mM})$.

Two lupanes exhibiting some activity against various viruses were isolated from Schefflera heptaphylla (L.) Frodin (Araliaceae). Their structures were similar to that of betulinic acid, but differed in the orientation of the hydroxyl in C-3. They were thus dubbed as 3-epi-betulinic acid derivatives. One of them was a 3-sulfate conjugate and the other a 4-methyl-4-carboxy derivative. The dicarboxylic acid had a maximum potency $\left(\mathrm{IC}_{50}<20 \mu \mathrm{g} / \mathrm{mL}\right)$ in the range of that of ribavirin, especially against the influenza $A$ virus ( $H 1 N 1$, in MDCK cells) and the Coxsackie virus B3 (in HEp-2 cells) [58].

In their study on the active principles of Ziziphus jujuba Mill. (Rhamnaceae), Hong et al. [59] found that betulinic acid inhibited the proliferation of the influenza A/PR/8 virus in A549 cells in a dose-dependent fashion $(0.4-50 \mu \mathrm{M})$. This effect was subsequently tested in mice to observe its therapeutic efficacy against 
the disease. Although betulinic acid was unable to reduce the weight loss caused by the infection, its activity was comparable to that of oseltamivir. From a histological point of view, the test compound reduced both the edema and the inflammation markers in the lungs.

Recent research, based on the idea that the antiviral action of vitamin $C$ could be combined with that of betulinic acid and/or other triterpenes, has focused on the synthesis and testing of various conjugates of ascorbate. The results showed that a triazole amide derived from dibenzylascorbic acid was the most potent compound ( $\bullet$ Fig. $\mathbf{6}$ ), but that it was only able to manifest its antiviral effect in the process of binding the virus to the host cell. Pretreatment of the virus produced a much greater inhibitory effect (87\%) than pretreatment of the cell (75\%). The main mechanism of action involved in binding the influenza A/WSN/33 virus to the surface of chicken erythrocytes was the inhibition of hemagglutinin-sialic acid binding [60].

Another virus susceptible to betulinic acid is hepatitis B, which has an obvious and important health impact. The inhibition of hepatitis $B$ replication exerted by the triterpene is based on the downregulation of SOD2 through the dephosphorylation (Ser133) of the cAMP response element-binding transcription factor at its binding site with the SOD2 promoter. In addition, betulinic acid was also shown to facilitate the translocation of the hepatitis B virus $X$ protein into the mitochondria of mouse hepatocytes. The antiviral activity was strictly dependent on SOD2 since overexpression of this enzyme was shown to suppress the effect [61].

\section{Cytotoxic and Potential Anticancer Properties}

Betulinic acid's antitumor activity is one of the most widely studied aspects of the compound's pharmacology. Although its effect extends to different cell types, it seems clear that the main mechanisms involved are the stimulation of apoptosis and the inhibition of kinases, both accompanied by a prominent antioxidant effect. Due to the sheer number of reviews on the cytotoxic and anticancer properties of betulinic acid and its derivatives, we have decided to limit our review to the most recent papers that were not included in the review published by Ali-Seyed et al. [62].

Betulinic acid was found to reduce many of the toxicity indicators of the antitumor agent doxorubicin, which is known to have strong cardiotoxic activity. These parameters, measured in human blood lymphocytes, include generation of reactive oxygen species, production of inflammatory cytokines such as IL-12 or TNF$\alpha$, alteration of mitochondrial membrane potential, and various morphological and histochemical changes to the apoptotic process. It is important to note that the betulinic acid used in this research consisted of a number of plurimolecular aggregates formed by a process of self-assembly, which is typical for this type of substance in hydroalcoholic solution. These self-assembled particles were found to exert proapoptotic and genotoxic activity in KG-1A and K562 leukemia cells, with higher efficacy than betulinic acid itself [63].

In an in vitro study using ovarian cancer cells (OVCAR 432 or RMS 13), a combination of betulinic acid with 5-fluorouracil produced a synergistic increase in the cytotoxic effect of this antitumor agent, with a concurrent increase in the subG 1 population

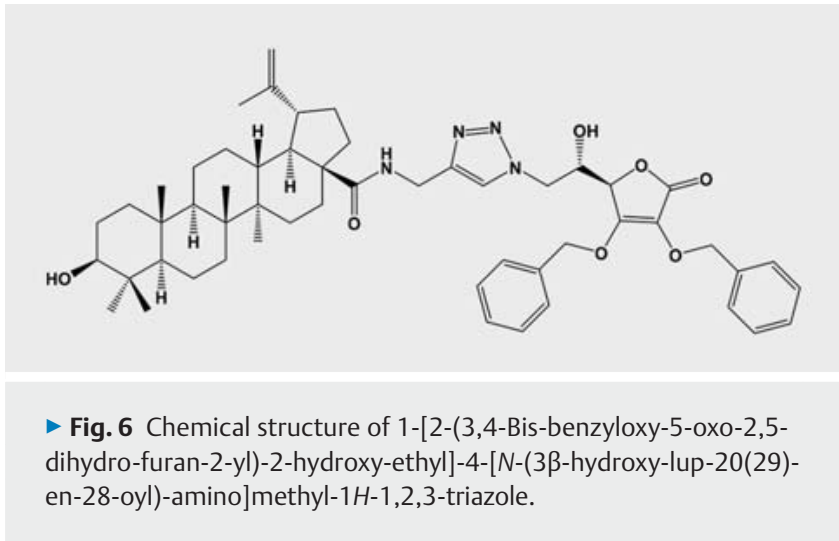

and a marked increase of apoptosis, measured by increases of cytochrome $c$ and caspase 3, among other parameters. However, when betulinic acid treatment preceded that of 5 -fluorouracil, there was a notable decrease in cytotoxicity, a result that was not explained by the authors [64].

In order to evaluate the effect of betulinic acid on tumor progression in the uterus, Karna et al. [65] studied tumor angiogenesis, assessed as the expression of hypoxia-inducible factor- $1 \alpha$ and one of its main target genes, that of vascular endothelial growth factor, in Ishikawa cells. This is a standard model used to study human endometrial adenocarcinoma. In this context, a strong inhibition of the expression of both proteins was observed, as well as a more moderate decrease in the activity of prolinase, which is associated with angiogenesis. This finding led to the proposal that the antitumor effects of the triterpene may, in part, be due to this activity.

A triazolonaphtol derivative of betulinic acid inhibited the expression of PI3K isoforms $\mathrm{p} 110 \alpha$ and $\mathrm{p} 85 \alpha$, as well as that of $\mathrm{p}-\mathrm{Akt}$ and NF-KB , in in vitro models of human leukemia (HL-60 cells) and breast cancer. This caused an arrest of the cell cycle in the $G_{0} / G_{1}$ stage due to an affectation of cyclin-dependent kinase inhibitor proteins and pGSK3 $\beta$ [66]. Another triazole derivative, $3\{1 N(2$-cyanophenyl)-1H-1,2,3-triazol-4yl\}methyloxy betulinic acid ( $\bullet$ Fig. 7), was also reported to boost these same activities [67].

Betulinic acid was also found to facilitate autophagy, even when it had been inhibited by cylosporin A. The induction of autophagy is one way to counteract mitochondrial death by apoptosis. Although the inhibition of caspases generally has an effect on apoptosis, these enzymes were not important in this case as they did not prevent cellular death through betulinic acid. After studying several cancer cell lines, the authors proposed that autophagy probably occurs in a later step, after the mitochondrial damage has taken place [68].

Khan et al. [69] studied various betulinic acid derivatives and found that one strongly inhibited the growth of some types of human cancer cells (HL-60, MIAPaCa2, PC-3, and A549) in a narrow margin of $5-7 \mu \mathrm{M}$. This compound ( $\bullet$ Fig. 8 ) was selected from a series of relatively simple aryl derivatives of the triazole ring at $\mathrm{C}$ 28 carboxyl. In HL-60 cells, an increase in the ratio of $\mathrm{Bax} / \mathrm{Bcl}-2$ proteins, a marked sign of apoptosis, was very apparent at 10 and $20 \mu \mathrm{M}$, and was accompanied by an accumulation of cells in the $G_{1}$ stage of the cell cycle. Furthermore, the mitochondrial 
membrane potential was decreased even at the lowest concentration assayed $(5 \mu \mathrm{M})$.

Several derivatives of betulinic and dihydrobetulinic acids, among them several difluorates, were synthesized from betulin. This type of double halogenation usually results in increased cytotoxic potency, which, in this case, was tested on lymphoblastic leukemia CCRF-CEM T cells. The best inhibitory results were obtained for those compounds with a 3-oxo group and a free carboxyl group (C-28), while reduction to dihydrobetulin derivatives did not significantly improve the activity [70].

Bache et al. [71] evaluated the improvements observed in betulinic acid's efficacy after acetylation in the C-28 primary alcohol analog and glycosylation of both C-3 (compound B-10) and the amino acid ester NVX-207 ( $\triangleright$ Fig. 9). The authors focused on the effects of these compounds on the growth of U251GM and U343GM glioblastoma cells with concomitant radiotherapy. The cells were examined for both their survival under conditions of normoxia and hypoxia with or without irradiation as well as for the expression of certain proteins, such as the apoptotic PARP, the inhibitor of apoptosis survivin, and the marker of tumor and hypoxia CAIX. Under hypoxia, CAIX levels, which were only measurable in this case, were virtually unchanged by betulinic derivatives, whereas survivin was dose-dependently downregulated. PARP protein expression was increased only at the highest concentration assayed $(10 \mu \mathrm{M})$ of B10.

The $p$-methoxy-phenylacetic ester of betulinic acid is known as SYK023 ( $\triangleright$ Fig. 10). This fairly simple derivative was assayed as an antitumor agent in a model of xenograft lung cancer in severely immunodeficient BALB/c mice as well as in a model of doxycycline-induced murine lung cancer. SYK023 substantively inhibited tumor progression in both models by means of endoplasmic reticulum stress-mediated apoptosis. The test compound affected the expression of different cyclins, inhibiting metastasis through the downregulation of synaptopodin, an actin-binding protein implicated in cytoskeletal function [72].

Another simple halogenated ester at C-3 is the dichloroacetate derivative, which was studied for its apoptotic, DNA damaging, and cytotoxic activity against several human cancer cell lines, DU 145 and PC-3 (prostate), MCF7, MDA-MB-231, and MDA-MB-468 (breast), and B16-F10 (melanoma). In each case, the potency of the ester surpassed that of betulinic acid. It was also more potent than the effect of betulinic acid + dichloroacetic acid combined as well as the effect observed in non-tumoral cells (WI-38 and 3T3 fibroblasts). In vivo, the results of the test compound on pulmonary metastases were positive, since both the number and, more importantly, the size of the nodules were notably reduced [73].

\section{Parasiticidal and Anti-Infectious Activity}

A study with several imidazolecarboxylate derivatives of betulin and betulinic acid found that several of them exhibited leishmanicidal activity. The compound with the highest potency $\left(\mathrm{IC}_{50}=\right.$ $25.8 \mu \mathrm{M})$ was an ester of 3-keto-betul-1-en-oic acid at C-2 $(\triangleright$ Fig. 11). When exposed to this imidazole derivative, the promastigote forms of Leishmania infantum suffered reductions in the size of both the whole cell and the flagellum. The associated loss of motility suggests that the compound alters the cytoskele-

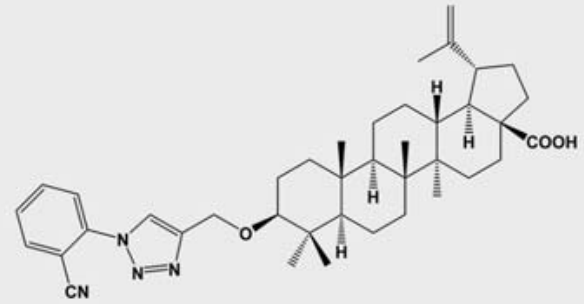

- Fig. 7 Chemical structure of $3\{1 \mathrm{~N}(2$-cyanophenyl)-1H-1,2,3-triazol-4yl]methyloxy betulinic acid.

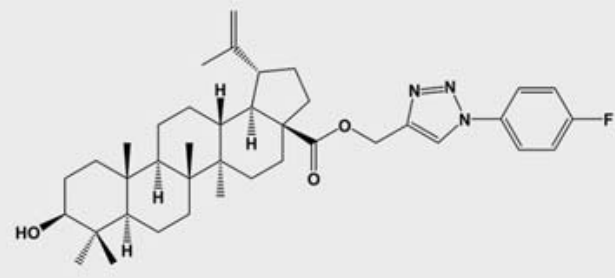

- Fig. 8 Chemical structure of $28\{1 N(4$-fluoro phenyl)-1H-1,2,3triazol-4-yl\}methyloxy betulinic ester.
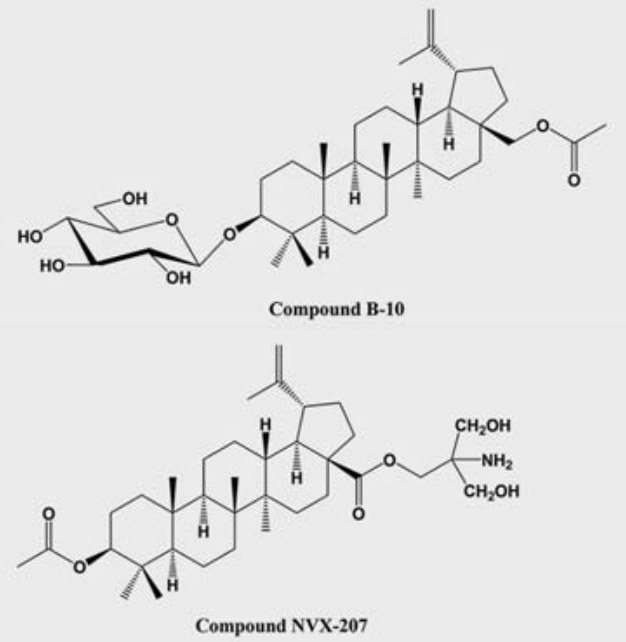

- Fig. 9 Chemical structure of C-28 and C-3 derivatives of betulinic acid (NVX-207 and B-10).

ton and affects mitochondrial function. The authors also observed cell cycle arrest in the $G_{0} / G_{1}$ phase, which would be consistent with the topoisomerase I inhibitory activity described above for other betulinic acid derivatives [74].

From the bark of Platanus acerifolia (Aiton) Willd. (Platanaceae) and apple peels, Innocente et al. obtained betulinic and ursolic acids [75]. These compounds, along with several alkyl-piperazinyl- 
amide derivatives, were evaluated for their toxicity against Trichomonas vaginalis trophozoites. In addition to the suppression of static and kinetic growth, the rupture of the parasite membrane was also studied. The most potent compound was the amide of 3-acetyl-betulinic acid with $\mathrm{N}, \mathrm{N}$-bis-2-aminoethylpiperazine. It should be noted that this compound was also the most potent against different species of fungi belonging to Candida, Tricophyton, Epidermophyton, Microsporum, and Scytalidium [76].

One of the most pressing health problems in the field of parasitology is the control of Schistosoma, both in its infective dimension and in its effects on the environment, by influencing its vectors. Recent research has focused on the activity of lupane derivatives. Although neither betulinic acid nor its alcoholic homologue betulin were found to be active, two ionic phospho-derivatives demonstrated significant inhibitory effects on Schistosoma mansoni, especially in vitro; these were the 30 -triphenylphosphonium derivatives of methyl 3-O-acetyl betulinate $\left(\mathrm{IC}_{50}=0.76 \mu \mathrm{g} / \mathrm{mL}\right)$ and 3,28-diacetylbetulin $\left(I C_{50}=0.64 \mu \mathrm{g} / \mathrm{mL}\right)$. Nevertheless, the efficacy observed in experiments in mice was slight [77].

Betulinic acid (but not its aldehyde homologue) obtained from the anti-infectious plant Callicarpa tomentosa (L.) L. (syn.: Callicarpa farinosa Roxb. ex C.B.Clarke, Lamiaceae) showed a potency $(\mathrm{MIC}=4-64 \mu \mathrm{g} / \mathrm{mL})$ similar to that of methicillin (MIC $=16-$ $64 \mu \mathrm{g} / \mathrm{mL}$ ) against Staphylococcus aureus in several methicillin-resistant strains. Still, it was far less effective than the more toxic antibiotic vancomycin. The genes affected by treatment with subinhibitory doses of betulinic acid were components of $A B C$ transporters (two), ribosomal assembly (one), and a two-component regulatory system (two). This last type is associated with both the virulence and antibiotic response of the bacterial cell [78].

Li et al. [79] studied the antimycobacterial constituents of the bark of Alnus incana (L.) Moench (Betulaceae), a species used as an anti-infection or antiseptic agent in different provinces of Canada. The active compounds, evaluated on Mycobacterium tuberculosis H37Ra, were triterpenic in nature. In this case, betulinic acid $\left(\mathrm{IC}_{50}=83.5 \mu \mathrm{M}\right.$; MIC $\left.>400 \mu \mathrm{g} / \mathrm{mL}\right)$ was not the most potent compound; that distinction went to betulin $\left(\mathrm{IC}_{50}=2.4 \mu \mathrm{M} ; \mathrm{MIC}=\right.$ $12.5 \mu \mathrm{g} / \mathrm{mL}$ ).

Of great interest is the work of Lingaraju et al. [80] on the effect of betulinic acid in a model of polymicrobial sepsis in mice with cecal ligation and a puncture to release intestinal contents. Intraperitoneal administration of the triterpenoid in doses ranging from 3 to $30 \mathrm{mg} / \mathrm{kg}$ clearly improved the essential parameters of antioxidant defense, catalase and superoxide dismutase, in the kidney, an organ that suffers the consequences of sepsis in a very prominent way. Regarding the inflammation markers, there was a dose-dependent reduction of metalloproteinase- 9 and TNF- $\alpha$, although there was no such effect on IL-6 or IL-10.

\section{Pharmacokinetic Properties}

Because of its poor solubility in water, betulinic acid has a low gastrointestinal absorption, which never exceeds $1 \%$ [9]. As a result of their work on pharmacokinetic and tissue distribution in CD-1 mice, Udeani et al. [81] proposed a two-compartment, first-order model for pharmacokinetic modeling. Betulinic acid at doses of 250 or $500 \mathrm{mg} / \mathrm{kg}$ (intraperitoneal) had distribution volumes of

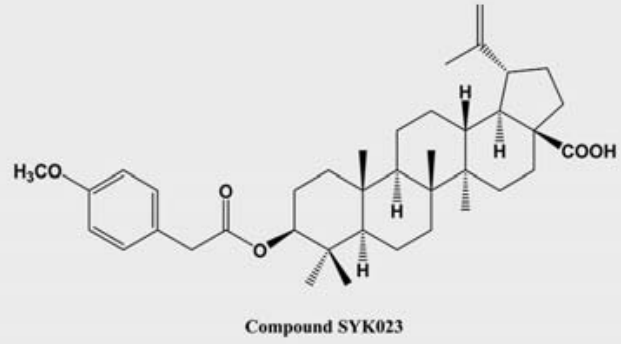

- Fig. 10 Chemical structure of compound SYK023.

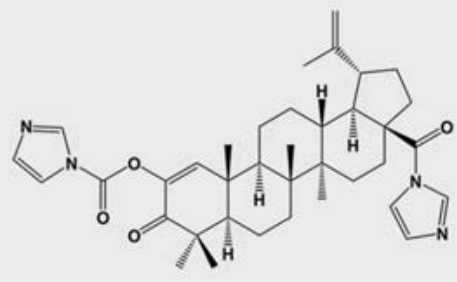

- Fig. 11 Chemical structure of compound AB13: 28-(1H-imidazole-1-yl)-3,28-dioxo-lup-1,20(29)-dien-2-yl-1H-imidazole-1-carboxylate.

$106 \mathrm{~L} / \mathrm{kg}$ and $108 \mathrm{~L} / \mathrm{kg}$, respectively, with elimination half-lives of 11.5 and $11.8 \mathrm{~h}$, and total clearances of 13.6 and $13.5 \mathrm{~L} / \mathrm{kg} / \mathrm{h}$, respectively, and serum concentrations peaking at 0.15 and $0.23 \mathrm{~h}$. The binding of betulinic acid to plasma proteins after intraperitoneal or intravenous administration in vivo was 99.99\% (15 and $25 \mu \mathrm{g} / \mathrm{mL}$ in mouse, rat, or dog plasma). At $5 \mu \mathrm{g} / \mathrm{mL}$, the serum protein binding reached $\geq 99.97 \%$ [82].

Betulinic acid distribution in tissues (at $500 \mathrm{mg} / \mathrm{kg}$, intraperitoneal) was as follows: fat tissues $(2260 \mu \mathrm{g} / \mathrm{g}$ at $24 \mathrm{~h})$, bladder $(3523 \mu \mathrm{g} / \mathrm{g}, 8 \mathrm{~h})$, lymph nodes $(4218 \mu \mathrm{g} / \mathrm{g}, 4 \mathrm{~h})$, mammary glands $(1184 \mu \mathrm{g} / \mathrm{g}, 24 \mathrm{~h})$, ovaries $(3055 \mu \mathrm{g} / \mathrm{g}, 4 \mathrm{~h})$, spleen $(1287 \mu \mathrm{g} / \mathrm{g}$, $24 \mathrm{~h})$, uterus $(908 \mu \mathrm{g} / \mathrm{g}, 24 \mathrm{~h})$, liver $(223.9 \mu \mathrm{g} / \mathrm{g}, 24 \mathrm{~h})$, and kidney $(95.8 \mu \mathrm{g} / \mathrm{g}, 24 \mathrm{~h})$, with serum levels of only $1.8 \mu \mathrm{g} / \mathrm{mL}$ after $24 \mathrm{~h}$ $[37,81]$. In their previous studies on the level of betulinic acid in the blood of athymic mice bearing human melanoma, as well as in tumor and tissue homogenates, Shin et al. [83] observed high concentrations in tumors $(452.2 \mathrm{mg} / \mathrm{g})$ and liver tissue (223.9 mg/g), whereas blood levels remained low $(1.8 \mathrm{mg} / \mathrm{mL})$.

Betulinic acid's low water solubility, described above, gives rise to certain problems for developing studies using the standard procedures for in vitro assays [37]. For this reason, researchers have studied different methods by which to dissolve the sample for use in pharmacological experiments, also in vivo. The results have been varied, as they are intrinsically influenced by the specific preparation techniques employed, that is, depending on the formulation or solvent used in the studies. Some relevant preparation techniques include the formation of a polyvinylpyrrolidone-betulinic acid complex [81], spray dried mucoadhesive microparticle formulations [84], phospholipid nanosome formats [85], and vari- 
ous structural modifications [52,67,86,87]. Although many of these studies focus mainly on improving the compound's pharmacological selectivity and potency as an anticancer or antiviral agent [87], several generalizations can be made. For example, in in vivo assays, the compound is principally administered intraperitoneally, with rats and mice being the animals of choice for these studies. To assess the concentrations of the triterpene, the principal systems of analysis used are HPLC-MS [88] and GC-FID [89].

Godugu et al. [84] used a patented, dual-channel, spray gun technology for improving both the oral bioavailability and the efficacy of betulinic acid. These researchers studied the gastrointestinal permeability of the compound in vitro on the Caco- 2 cell monolayer. To assess the oral bioavailability and pharmacokinetic profile, they employed Sprague Dawley rats. These studies demonstrated that betulinic acid spray in a dried mucoadhesive microparticle formulation results in a significant 3.90-fold increase in plasma $C_{\max }$ concentration, with the area under the curve level increasing 7.41-fold with this formulation.

The biotransformation of betulinic acid was studied in an in vitro model of metabolism designed to predict the compound's potential mammalian metabolites. The sites of metabolism mediated by human CYP enzyme systems in the acid were also studied. The results indicated that the free carboxylic acid group (C-28) of this triterpene may act as a substrate for human CYP2C9, with the most likely sites of oxidative metabolism being the carbons C-23 and C-6a. In addition to CYP2C9, a homologous model for human CYP3A4 predicted similar sites of metabolism: positions C- 6 and C-23 or C-24 [37].

Because the major problem for the potential therapeutic use of betulinic acid is its poor hydrosolubility, which limits its application to a topical use, various derivatives and forms of administration have been proposed. Modifications at positions C-3, C-20, and $\mathrm{C}-28$ have been shown to increase the solubility without affecting the pharmacological activity. Alternatively, new administration routes have been proposed, such as in the form of liposomes, transdermal applications, nanoemulsions, and slow-release materials. In this context, further studies are necessary to develop novel administration formulations and methods, and this does indeed constitute one of the biggest challenges over the next few years [90].

\section{Toxicological Aspects}

Various studies have demonstrated a selective effect of betulinic acid on cancerous cells compared to normal cells, along with a low toxicity in vitro against normal dermal fibroblast and peripheral blood lymphocytes with respect to different human neoplastic cell lines [91]. In addition, in vitro studies with Madin Darby kidney cells showed that betulinic acid produces a significant increase in the concentration of intracellular-free calcium with only a slight decrease in cell viability [92]. These results indicate that, at standard doses, betulinic acid possesses a very narrow spectrum of cytotoxicity; indeed, only minor negative effects were observed at relatively high therapeutic doses [37].

In this regard, several in vivo studies have been developed, with varied results. For example, in 1999, Steele et al. [93] found that betulinic acid ( $250 \mathrm{mg} / \mathrm{kg} /$ day for 4 days, intraperitoneal) admin- istered to mice preinfected with Plasmodium berghei caused the death of one of the experimental mice. However, in a previous screening, betulinic acid had shown no toxicity in rats (200 and $400 \mathrm{mg} / \mathrm{kg}$, intraperitoneal) or mice $(500 \mathrm{mg} / \mathrm{kg}, 6$ doses, each 4th day, or $250 \mathrm{mg} / \mathrm{kg}, 6$ doses, each 3rd day) [37].

\section{Summary, Future Perspectives, and Conclusions}

The reduction of glycemia through the inhibition of $\alpha$-amylase and $\alpha$-glucosidase, together with the stimulation of glucose uptake and glycogen synthesis through the AMPK-GSK3 $\beta$ pathway, constitute relevant mechanisms that justify the potential of betulinic acid as an antidiabetic agent. These effects act together with the increase of insulin biosynthesis, secretion, and sensitivity through the inhibition of PTP-1B and the resulting increase of PI3K/Akt activity. Moreover, the activation of AMPK suppresses the mRNA expression and nuclear translocation of SREBP-1 and activates PPAR- $\alpha$, which positively regulates lipid oxidation because PPAR- $\alpha$ plays a critical role in the regulation of cellular uptake, activation, and oxidation of fatty acids. In addition, betulinic acid has been shown to decrease abdominal fat accumulation, plasma triglycerides, and total cholesterol, while simultaneously increasing levels of the anorexigenic hormone and decreasing those of the orexigenic hormone ghrelin in plasma. Betulinic acid also inhibits pancreatic lipase and reduces lipid absorption in the small intestine while increasing fat mobilization through lipolysis in adipose tissues. It also reduces cholesterol absorption in the intestine via inhibition of hACAT.

The third relevant symptom of metabolic syndrome is inflammation. With this in mind, the anti-inflammatory effects of betulinic acid could be of great interest in the treatment of this increasingly prevalent pathology. To date, in vivo experiments have demonstrated that the activity of betulinic acid depends on the inhibition of protein kinase $C$. Moreover, the compound's inhibitory effects on both PLA 2 and NF- $\kappa$ B activation, as well as on the NF- $\kappa$ Bdependent gene expressions of cyclooxygenase-2 and matrix metalloproteinase-9, endow it with anti-inflammatory properties. Betulinic acid also decreases collagen biosynthesis, most likely through the disruption of the insulin-like growth factor I receptor, which regulates collagen synthesis [94]. However, while these authors observed that this effect was accompanied by an increased expression of NF- $k B$, a known inhibitor of collagen gene expression, Takada and Aggarwal [38] had previously described its inhibitory effects on NF- $\kappa$ B activation in different tumor cell lines. These contradictory effects are most likely due to the different inductors and cell lines used for NF- $K B$ in various studies. For example, betulinic acid blocked the activation of NF- $\kappa$ B in colon cancer (HCT116 and $\mathrm{Caco} 2)$ and lung cancer (H1299) cells with different agents (IL-1 $\beta$, okadaic acid, $\mathrm{H}_{2} \mathrm{O}_{2}$, phorbol-esters, and TNF- $\alpha$ ), whereas Karna and Palka reported a direct effect of betulinic acid on human endometrial adenocarcinoma cells (non-stimulated) [94].

Reductions of central obesity and insulin resistance, along with control of the proinflammatory state, are all desirable in order to avoid atherogenic dyslipidemia and endothelial dysfunction in vascular inflammation processes. Betulinic acid increases the 
production of nitric oxide by activating the endothelial nitric oxide synthase activity that is linked to the activation of the estrogen receptor, all of which are involved in endothelial integrity.

The second group of studies on betulinic acid have focused on its potential as an antiviral and anticancer agent. In both cases, the effect of its derivatives is higher than that of the compound itself. For example, bevirimat or 3-O-(3',3'-dimethylsuccinyl)betulinic acid and its derivatives were found to inhibit reverse transcriptase activity. A benzoic substitution at C-3 in 2,3-dehydrobetulinic acid with an ortho halogen substitution in the benzoic moiety showed the highest potency of all the inhibitors of HIV-1 maturation. Other antiviral derivatives were obtained from the original triterpene by modifying different characteristics, such as C-28 derivatives, in order to increase its solubility and improve its potency. In this way, its effect on several viruses, such as the influenza $A$ virus (H1N1), the Coxsackie virus B3, herpes viruses (HSV-1), and hepatitis B, was also examined. In these studies, the best results were obtained with conjugated structures of the triazole amide derived from dibenzylascorbic acid against the influenza A virus. Similar cases were reported for studies on the cytotoxic and antitumor properties of the compound. In these cases, betulinic acid showed both proapoptotic and genotoxic activity, though its derivatives showed higher efficacy when assayed against various leukemia cells. In some cases, the activity was increased either through modification of the pharmacokinetic properties, through different administration routes (spray dried mucoadhesive microparticle formulations or phospholipid nanosomes), or, as described above, through structural modifications.

Betulinic acid has serious limitations with regard to its direct application as a medicinal agent; however, its derivatives could be highly interesting compounds for treating various pathologies. For this reason, future studies should focus on the elaboration of new derivatives with the activities described above.

In conclusion, betulinic acid should be considered a promising drug for controlling metabolic syndrome in all its different aspects, including as a means to reduce glycemia and inflammation, as well as exerting an effect on triglycerides and cholesterol. In addition, the possible use of some of the acid's derivatives in antiviral or oncological pharmacological interventions is also relevant, particularly for compounds such as bevirimat, which acts an inhibitor of reverse transcriptase activity.

\section{Conflict of Interest}

The authors state no conflict of interest.

\section{References}

[1] Moghaddam MG, Ahmad JBH, Samzadeh-Kermani A. Biological activity of betulinic acid: a review. Phamacol Pharm 2012; 3: 119-123

[2] Recio MC, Giner RM, Máñez S, Gueho J, Julien HR, Hostettmann K, Ríos JL. Investigations on the steroidal anti-inflammatory activity of triterpenoids from Diospyros leucomelas. Planta Med 1995; 61: 9-12

[3] Aiken C, Chen CH. Betulinic acid derivatives as HIV-1 antivirals. Trends Mol Med 2005; 11: 31-36

[4] Rajendran P, Jaggi M, Singh MK, Mukherjee R, Burman AC. Pharmacological evaluation of C-3 modified betulinic acid derivatives with potent anticancer activity. Invest New Drugs 2008; 26: 25-34
[5] Zhang X, Hu J, Chen Y. Betulinic acid and the pharmacological effects of tumor suppression (Review). Mol Med Rep 2016; 14: 4489-4495

[6] Zhang DM, Xu HG, Wang L, Li Y], Sun PH, Wu XM, Wang G], Chen WM, Ye WC. Betulinic acid and its derivatives as potential antitumor agents. Med Res Rev 2015; 35: 1127-1155

[7] Gheorgheosu D, Duicu O, Dehelean C, Soica C, Muntean D. Betulinic acid as a potent and complex antitumor phytochemical: a minireview. Anticancer Agents Med Chem 2014; 14: 936-945

[8] Jonnalagadda SC, Corsello MA, Sleet CE. Betulin-betulinic acid natural product based analogs as anti-cancer agents. Anticancer Agents Med Chem 2013; 13: 1477-1499

[9] Silva FS, Oliveira PJ, Duarte MF. Oleanolic, ursolic, and betulinic acids as food supplements or pharmaceutical agents for type 2 diabetes: promise or illusion? J Agric Food Chem 2016; 64: 2991-3008

[10] Kim J, Lee YS, Kim CS, Kim JS. Betulinic acid has an inhibitory effect on pancreatic lipase and induces adipocyte lipolysis. Phytother Res 2012; 26: 1103-1106

[11] Gautam R, Jachak SM. Recent developments in anti-inflammatory natural products. Med Res Rev 2009; 29: 767-820

[12] Kaur J. A comprehensive review on metabolic syndrome. Cardiol Res Pract 2014; 2014: 943162

[13] O’Neill S, O’Driscoll L. Metabolic syndrome: a closer look at the growing epidemic and its associated pathologies. Obes Rev 2015; 16: 1-12

[14] Kumar S, Kumar V, Prakash O. Enzymes inhibition and antidiabetic effect of isolated constituents from Dillenia indica. Biomed Res Int 2013; 2013: 382063

[15] de Melo CL, Queiroz MG, Arruda Filho AC, Rodrigues AM, de Sousa DF, Almeida JG, Pessoa OD, Silveira ER, Menezes DB, Melo TS, Santos FA, Rao VS. Betulinic acid, a natural pentacyclic triterpenoid, prevents abdominal fat accumulation in mice fed a high-fat diet. J Agric Food Chem 2009; 57: 8776-8781

[16] He QQ, Yang L, Zhang JY, Ma JN, Ma CM. Chemical constituents of goldred apple and their $\alpha$-glucosidase inhibitory activities. J Food Sci 2014; 79: C1970-C1983

[17] Castro AJ, Frederico MJ, Cazarolli LH, Bretanha LC, Tavares LC, Buss ZS, Dutra MF, de Souza AZ, Pizzolatti MG, Silva FR. Betulinic acid and $1,25(\mathrm{OH})_{2}$ vitamin $D_{3}$ share intracellular signal transduction in glucose homeostasis in soleus muscle. Int J Biochem Cell Biol 2014; 48: 18-27

[18] Wen X, Sun H, Liu J, Cheng K, Zhang P, Zhang L, Hao J, Zhang L, Ni P, Zographos SE, Leonidas DD, Alexacou KM, Gimisis T, Hayes JM, Oikonomakos NG. Naturally occurring pentacyclic triterpenes as inhibitors of glycogen phosphorylase: synthesis, structure-activity relationships, and X-ray crystallographic studies. J Med Chem 2008; 51: 3540 3554

[19] Ha DT, Tuan DT, Thu NB, Nhiem NX, Ngoc TM, Yim N, Bae K. Palbinone and triterpenes from Moutan Cortex (Paeonia suffruticosa, Paeoniaceae) stimulate glucose uptake and glycogen synthesis via activation of AMPK in insulin-resistant human HepG2 cells. Bioorg Med Chem Lett 2009; 19: 5556-5559

[20] Kim SJ, Quan HY, Jeong KJ, Kim DY, Kim G, Jo HK, Chung SHJ. Beneficial effect of betulinic acid on hyperglycemia via suppression of hepatic glucose production. J Agric Food Chem 2014; 62: 434-442

[21] Heiss EH, Kramer MP, Atanasov AG, Beres H, Schachner D, Dirsch VM. Glycolytic switch in response to betulinic acid in non-cancer cells. PLoS One 2014; 9: e115683

[22] Choi JY, Na M, Hwang IH, Lee SH, Bae EY, Yeon BK, Ahn JS. Isolation of betulinic acid, its methyl ester and guaiane sesquiterpenoids with protein tyrosine phosphatase $1 \mathrm{~B}$ inhibitory activity from the roots of Saussurea lappa C.B. Clarke. Molecules 2009; 14: 266-272

[23] Li D, Li W, Higai K, Koike K. Protein tyrosine phosphatase 1B inhibitory activities of ursane- and lupane-type triterpenes from Sorbus pohuashanensis. J Nat Med 2014; 68: 427-431 
[24] Trauner M, Claudel T, Fickert P, Moustafa T, Wagner M. Bile acids as regulators of hepatic lipid and glucose metabolism. Dig Dis 2010; 28: 220224

[25] Genet C, Strehle A, Schmidt C, Boudjelal G, Lobstein A, Schoonjans K, Souchet M, Auwerx J, Saladin R, Wagner A. Structure-activity relationship study of betulinic acid, a novel and selective TGR5 agonist, and its synthetic derivatives: potential impact in diabetes. J Med Chem 2010; 53: $178-190$

[26] Pols TW, Noriega LG, Nomura M, Auwerx J, Schoonjans K. The bile acid membrane receptor TGR5: a valuable metabolic target. Dig Dis 2011; 29: $37-44$

[27] Thomas C, Gioiello A, Noriega L, Strehle A, Oury J, Rizzo G, Macchiarulo A, Yamamoto H, Mataki C, Pruzanski M, Pellicciari R, Auwerx J, Schoonjans K. TGR5-mediated bile acid sensing controls glucose homeostasis. Cell Metabol 2009; 10: 167-177

[28] Jang DS, Lee GY, Kim J, Lee YM, Kim JM, Kim YS, Kim JS. A new pancreatic lipase inhibitor isolated from the roots of Actinidia arguta. Arch Pharm Res 2008; 31: 666-670

[29] Lee WS, Im KR, Park YD, Sung ND, Jeong TS. Human ACAT-1 and ACAT-2 inhibitory activities of pentacyclic triterpenes from the leaves of Lycopus lucidus Turcz. Biol Pharm Bull 2006; 29: 382-384

[30] Quan HY, Kim DY, Kim S], Jo HK, Kim GW, Chung SH. Betulinic acid alleviates non-alcoholic fatty liver by inhibiting SREBP1 activity via the AMPK-mTOR-SREBP signaling pathway. Biochem Pharmacol 2013; 85: $1330-1340$

[31] Ríos JL, Francini F, Schinella GR. Natural products for the treatment of type 2 diabetes mellitus. Planta Med 2015; 81: 975-994

[32] Cho Y, Hazen BC, Russell AP, Kralli A. Peroxisome proliferator-activated receptor $\gamma$ coactivator 1 (PGC-1)- and estrogen-related receptor (ERR)induced regulator in muscle 1 (Perm 1 ) is a tissue-specific regulator of oxidative capacity in skeletal muscle cells. J Biol Chem 2013; 288 : 25207-25218

[33] Chung MY, Rho MC, Lee SW, Park HR, Kim K, Lee IA, Kim DH, Jeune KH, Lee HS, Kim YK. Inhibition of diacylglycerol acyltransferase by betulinic acid from Alnus hirsuta. Planta Med 2006; 72: 267-269

[34] Huguet A, Recio MC, Máñez S, Giner R, Ríos JL. Effect of triterpenoids on the inflammation induced by protein kinase $C$ activators, neuronally acting irritants and other agents. Eur J Pharmacol 2000; 410: 69-81

[35] Wang BH, Polya GM. Selective inhibition of cyclic AMP-dependent protein kinase by amphiphilic triterpenoids and related compounds. Phytochemistry 1996; 41: 55-63

[36] Bernard P, Scior T, Didier B, Hibert M, Berthon JY. Ethnopharmacology and bioinformatic combination for leads discovery: application to phospholipase $A_{2}$ inhibitors. Phytochemistry 2001; 58: 865-874

[37] Cichewicz RH, Kouzi SA. Chemistry, biological activity, and chemotherapeutic potential of betulinic acid for the prevention and treatment of cancer and HIV infection. Med Res Rev 2004; 24: 90-114

[38] Takada Y, Aggarwal BB. Betulinic acid suppresses carcinogen-induced NF- $\kappa B$ activation through inhibition of $I_{\kappa} B \alpha$ kinase and $p 65$ phosphorylation: abrogation of cyclooxygenase- 2 and matrix metalloprotease-9. J Immunol 2003; 171: 3278-3286

[39] Su BN, Cuendet M, Farnsworth NR, Fong HHS, Pezzuto JM, Kinghorn AD. Activity-guided fractionation of the seeds of Ziziphus jujuba using a cyclooxygenase-2 inhibitor assay. Planta Med 2002; 68: 1125-1128

[40] Ryu SY, Oak MH, Yoon SK, Cho DI, Yoo GS, Kim TS, Kim KM. Anti-allergic and anti-inflammatory triterpenes from the herb of Prunella vulgaris. Planta Med 2000; 66: 358-360

[41] Jain MK, Yu BZ, Rogers JM, Smith AE, Boger ET, Ostrander RL, Rheingold AL. Specific competitive inhibitor of secreted phospholipase $A_{2}$ from berries of Schinus terebinthifolius. Phytochemistry 1995; 39: 537-547

[42] Giner-Larza EM, Máñez S, Giner RM, Recio MC, Prieto JM, Cerdá-Nicolás M, Ríos JL. Anti-inflammatory triterpenes from Pistacia terebinthus galls. Planta Med 2002; 68: 311-315
[43] Yueqin Z, Recio MC, Máñez S, Giner RM, Cerdá-Nicolás M, Ríos JL. Isolation of two triterpenoids and a biflavanone with anti-Inflammatory activity from Schinus molle fruits. Planta Med 2003; 69: 893-898

[44] Yoon JJ, Lee Y], Kim JS, Kang DG, Lee HS. Protective role of betulinic acid on TNF- $\alpha$-induced cell adhesion molecules in vascular endothelial cells. Biochem Biophys Res Commun 2010; 391: 96-101

[45] Zhao G], Tang SL, Lv YC, Ouyang XP, He PP, Yao F, Chen W], Lu Q, Tang YY, Zhang M, Fu Y, Zhang DW, Yin K, Tang CK. Antagonism of betulinic acid on LPS-mediated inhibition of ABCA1 and cholesterol efflux through inhibiting nuclear factor-kappaB signaling pathway and miR-33 expression. PLoS One 2013; 8: e74782

[46] Jin T, Yu H, Huang XF. Selective binding modes and allosteric inhibitory effects of lupane triterpenes on protein tyrosine phosphatase 1B. Sci Rep 2016; 6: 20766

[47] Kim HI, Quan FS, Kim JE, Lee NR, Kim HJ, Jo SJ, Lee CM, Jang DS, Inn KS Inhibition of estrogen signaling through depletion of estrogen receptor alpha by ursolic acid and betulinic acid from Prunella vulgaris var. lilacina. Biochem Biophys Res Commun 2014; 451: 282-287

[48] Tzenov YR, Andrews P, Voisey K, Gai L, Carter B, Whelan K, Popadiuk C, Kao KR. Selective estrogen receptor modulators and betulinic acid act synergistically to target ER $\alpha$ and SP1 transcription factor dependent Pygopus expression in breast cancer. J Clin Pathol 2016; 69: 518-526

[49] Hohmann N, Xia N, Steinkamp-Fenske K, Förstermann U, Li H. Estrogen receptor xignaling and the PI3K/Akt pathway are involved in betulinic acid-induced eNOS activation. Molecules 2016; 21: E973

[50] Yogeeswari P, Sriram D. Betulinic acid and its derivatives: a review on their biological properties. Curr Med Chem 2005; 12: 657-666

[51] Swidorski J], Liu Z, Sit SY, Chen J, Chen Y, Sin N, Venables BL, Parker DD, Nowicka-Sans B, Terry BJ, Protack T, Rahematpura S, Hanumegowda U, Jenkins S, Krystal M, Dicker IB, Meanwell NA, Regueiro-Ren A. Inhibitors of HIV-1 maturation: Development of structure-activity relationship for C-28 amides based on C-3 benzoic acid-modified triterpenoids. Bioorg Med Chem Lett 2016; 26: 1925-1930

[52] Liu Z, Swidorski J], Nowicka-Sans B, Terry B, Protack T, Lin Z, Samanta H, Zhang S, Li Z, Parker DD, Rahematpura S, Jenkins S, Beno BR, Krystal M, Meanwell NA, Dicker IB, Regueiro-Ren A. C-3 benzoic acid derivatives of C-3 deoxybetulinic acid and deoxybetulin as HIV-1 maturation inhibitors. Bioorg Med Chem 2016; 24: 1757-1770

[53] Kashiwada Y, Hashimoto F, Cosentino LM, Chen CH, Garrett PE, Lee KH. Betulinic acid and dihydrobetulinic acid derivatives as potent anti-HIV agents. J Med Chem 1996; 39: 1016-1017

[54] Urano E, Ablan SD, Mandt R, Pauly GT, Sigano DM, Schneider JP, Martin DE, Nitz TJ, Wild CT, Freed EO. Alkyl amine bevirimat derivatives are potent and broadly active HIV-1 maturation inhibitors. Antimicrob Agents Chemother 2015; 60: 190-197

[55] Li ], Goto M, Yang X, Morris-Natschke SL, Huang L, Chen CH, Lee KH. Fluorinated betulinic acid derivatives and evaluation of their anti-HIV activity. Bioorg Med Chem Lett 2016; 26: 68-71

[56] Heidary Navid M, Laszczyk-Lauer MN, Reichling J, Schnitzler P. Pentacyclic triterpenes in birch bark extract inhibit early step of herpes simplex virus type 1 replication. Phytomedicine 2014; 21: 1273-1280

[57] Visalli RJ, Ziobrowski H, Badri KR, He J], Zhang X, Arumugam SR, Zhao H. Ionic derivatives of betulinic acid exhibit antiviral activity against herpes simplex virus type-2 (HSV-2), but not HIV-1 reverse transcriptase. Bioorg Med Chem Lett 2015; 25: 3168-3171

[58] Li Y, Jiang R, Ooi LS, But PP, Ooi VE. Antiviral triterpenoids from the medicinal plant Schefflera heptaphylla. Phytother Res 2007; 21: 466-470

[59] Hong EH, Song JH, Kang KB, Sung SH, Ko HJ, Yang H. Anti-influenza activity of betulinic acid from Zizyphus jujuba on influenza A/PR/8 virus. Biomol Ther (Seoul) 2015; 23: 345-349

[60] Wang H, Xu R, Shi Y, Si L, Jiao P, Fan Z, Han X, Wu X, Zhou X, Yu F, Zhang $Y$, Zhang L, Zhang L, Zhou D, Xiao S. Design, synthesis and biological evaluation of novel L-ascorbic acid-conjugated pentacyclic triterpene 
derivatives as potential influenza virus entry inhibitors. Eur ] Med Chem 2016; 110: 376-388

[61] Yao D, Li H, Gou Y, Zhang H, Vlessidis AG, Zhou H, Evmiridis NP, Liu Z. Betulinic acid-mediated inhibitory effect on hepatitis B virus by suppression of manganese superoxide dismutase expression. FEBS ] 2009; 276 : 2599-2614

[62] Ali-Seyed M, Jantan I, Vijayaraghavan K, Bukhari SN. Betulinic acid: recent advances in chemical modifications, effective delivery, and molecular mechanisms of a promising anticancer therapy. Chem Biol Drug Des 2016; 87: 517-536

[63] Dash SK, Chattopadhyay S, Dash SS, Tripathy S, Das B, Mahapatra SK, Bag BG, Karmakar P, Roy S. Self-assembled nano fibers of betulinic acid: A selective inducer for ROS/TNF-alpha pathway mediated leukemic cell death. Bioorg Chem 2015; 63: 85-100

[64] Wang YJ, Liu JB, Dou YC. Sequential treatment with betulinic acid followed by 5 -fluorouracil shows synergistic cytotoxic activity in ovarian cancer cells. Int J Clin Exp Pathol 2015; 8: 252-259

[65] Karna E, Szoka L, Palka JA. Betulinic acid inhibits the expression of hypoxia-inducible factor 1 alpha and vascular endothelial growth factor in human endometrial adenocarcinoma cells. Mol Cell Biochem 2010; 340: $15-20$

[66] Majeed R, Hamid A, Sangwan PL, Chinthakindi PK, Koul S, Rayees S, Singh G, Mondhe DM, Mintoo MJ, Singh SK, Rath SK, Saxena AK. Inhibition of phosphotidylinositol-3 kinase pathway by a novel naphthol derivative of betulinic acid induces cell cycle arrest and apoptosis in cancer cells of different origin. Cell Death Dis 2014; 5: e1459

[67] Majeed R, Hussain A, Sangwan PL, Chinthakindi PK, Khan I, Sharma PR, Koul S, Saxena AK, Hamid A. PI3K target based novel cyano derivative of betulinic acid induces its signaling inhibition by down-regulation of pGSK3 $\beta$ and cyclin D1 and potentially checks cancer cell proliferation. Mol Carcinog 2016; 55: 964-976

[68] Potze L, Mullauer FB, Colak S, Kessler JH, Medema JP. Betulinic acid-induced mitochondria-dependent cell death is counterbalanced by an autophagic salvage response. Cell Death Dis 2014; 5: e1169

[69] Khan I, Guru SK, Rath SK, Chinthakindi PK, Singh B, Koul S, Bhushan S, Sangwan PL. A novel triazole derivative of betulinic acid induces extrinsic and intrinsic apoptosis in human leukemia HL-60 cells. Eur J Med Chem 2016; 108: 104-116

[70] Borkova L, Jasikova L, Rehulka J, Frisonsova K, Urban M, Frydrych I, Popa I, Hajduch M, Dickinson NJ, Vlk M, Dzubak P, Sarek J. Synthesis of cytotoxic 2,2-difluoroderivatives of dihydrobetulinic acid and allobetulin and study of their impact on cancer cells. Eur J Med Chem 2015; 96: 482-490

[71] Bache M, Bernhardt S, Passin S, Wichmann H, Hein A, Zschornak M, Kappler M, Taubert H, Paschke R, Vordermark D. Betulinic acid derivatives NVX-207 and B10 for treatment of glioblastoma - an in vitro study of cytotoxicity and radiosensitization. Int J Mol Sci 2014; 15: 1977719790

[72] Hsu TI, Chen YJ, Hung CY, Wang YC, Lin SJ, Su WC, Lai MD, Kim SY, Wang Q, Qian K, Goto M, Zhao Y, Kashiwada Y, Lee KH, Chang WC, Hung J]. A novel derivative of betulinic acid, SYK023, suppresses lung cancer growth and malignancy. Oncotarget 2015; 6: 13671-13687

[73] Saha S, Ghosh M, Dutta SK. A potent tumoricidal co-drug 'Bet-CA' - an ester derivative of betulinic acid and dichloroacetate selectively and synergistically kills cancer cells. Sci Rep 2015; 5: 7762

[74] Sousa MC, Varandas R, Santos RC, Santos-Rosa M, Alves V, Salvador JA. Antileishmanial activity of semisynthetic lupane triterpenoids betulin and betulinic acid derivatives: synergistic effects with miltefosine. PLoS One 2014; 9: e89939

[75] Innocente AM, Vieira PB, Frasson AP, Casanova BB, Gosmann G, Gnoatto SC, Tasca T. Anti-Trichomonas vaginalis activity from triterpenoid derivatives. Parasitol Res 2014; 113: 2933-2940

[76] Innocente A, Casanova BB, Klein F, Lana AD, Pereira D, Muniz MN, Sonnet P, Gosmann G, Fuentefria AM, Gnoatto SC. Synthesis of isosteric triterpe- noid derivatives and antifungal activity. Chem Biol Drug Des 2014; 83: 344-349

[77] Spivak AY, Keiser ], Vargas M, Gubaidullin RR, Nedopekina DA, Shakurova ER, Khalitova RR, Odinokov VN. Synthesis and activity of new triphenylphosphonium derivatives of betulin and betulinic acid against Schistosoma mansoni in vitro and in vivo. Bioorg Med Chem 2014; 22: 6297-6304

[78] Chung PY, Chung LY, Navaratnam P. Potential targets by pentacyclic triterpenoids from Callicarpa farinosa against methicillin-resistant and sensitive Staphylococcus aureus. Fitoterapia 2014; 94: 48-54

[79] Li H, Webster D, Johnson JA, Gray CA. Anti-mycobacterial triterpenes from the Canadian medicinal plant Alnus incana. J Ethnopharmacol 2015; 165: 148-151

[80] Lingaraju MC, Pathak NN, Begum J, Balaganur V, Ramachandra HD, Bhat RA, Ram M, Singh V, Kandasamy K, Kumar D, Kumar D, Tandan SK. Betulinic acid attenuates renal oxidative stress and inflammation in experimental model of murine polymicrobial sepsis. Eur J Pharm Sci 2015; 70: $12-21$

[81] Udeani GO, Zhao GM, Geun Shin Y, Cooke BP, Graham J, Beecher CW, Kinghorn AD, Pezzuto JM. Pharmacokinetics and tissue distribution of betulinic acid in CD-1 mice. Biopharm Drug Dispos 1999; 20: 379-383

[82] Cheng X, Shin YG, Levine BS, Smith AC, Tomaszewski JE, van Breemen RB. Quantitative analysis of betulinic acid in mouse, rat and dog plasma using electrospray liquid chromatography/mass spectrometry. Rapid Commun Mass Spectrom 2003; 17: 2089-2092

[83] Shin YG, Cho KH, Chung SM, Graham J, Gupta TKD, Pezzuto JM. Determination of betulinic acid in mouse blood, tumor, and tissue homogenates by liquid chromatography - electrospray mass spectrometry. J Chromatogr B 1999; 732: 331-336

[84] Godugu C, Patel AR, Doddapaneni R, Somagoni ], Singh M. Approaches to improve the oral bioavailability and effects of novel anticancer drugs berberine and betulinic acid. PLoS One 2014; 9: e89919

[85] Castor TP. Phospholipid nanosomes. Curr Drug Deliv 2005; 2: 329-340

[86] Honda T, Liby KT, Su X, Sundararajan C, Honda Y, Suh N, Risingsong R, Williams CR, Royce DB, Sporn MB, Gribble GW. Design, synthesis, and anti-inflammatory activity both in vitro and in vivo of new betulinic acid analogues having an enone functionality in ring A. Bioorg Med Chem Lett 2006; 16: 6306-6309

[87] Dang Z, Qian K, Ho P, Zhu L, Lee KH, Huang L, Chen CH. Synthesis of betulinic acid derivatives as entry inhibitors against HIV-1 and bevirimatresistant HIV-1 variants. Bioorg Med Chem Lett 2012; 22: 5190-5194

[88] Zhao L, Li W, Li Y, Xu H, Lv L, Wang X, Chai Y, Zhang G. Simultaneous determination of oleanolic and ursolic acids in rat plasma by HPLC-MS: application to a pharmacokinetic study after oral administration of different combinations of QingGanSanjie decoction extracts. J Chromatogr Sci 2015; 53: 1185-1192

[89] Rada M, Castellano JM, Perona JS, Guinda Á. GC-FID determination and pharmacokinetic studies of oleanolic acid in human serum. Biomed Chromatogr 2015; 29: 1687-1692

[90] Csuk R. Betulinic acid and its derivatives: a patent review (2008-2013). Expert Opin Ther Pat 2014; 24: 913-923

[91] Zuco V, Supino R, Righetti SC, Cleris K, Marchesi E, Gambacorti-Passerini C, Formelli F. Selective cytotoxicity of betulinic acid on tumor cell lines, but not normal cells. Cancer Lett 2002; 175: 17-25

[92] Chou KJ, Fang HC, Chung HM, Cheng JS, Lee KC, Tseng LL, Tang KY, Jan CR. Effect of betulinic acid on intracellular-free $\mathrm{Ca}^{2+}$ levels in Madin Darby canine kidney cells. Eur J Pharmacol 2000; 408: 99-106

[93] Steele JCP, Warhurst DC, Kirby GC, Simmonds MSI. In vitro and in vivo evaluation of betulinic acid as an antimalarial. Phytother Res 1999; 13 : 115-119

[94] Karna E, Palka JA. Mechanism of betulinic acid inhibition of collagen biosynthesis in human endometrial adenocarcinoma cells. Neoplasma 2009; 56: 361-366 